\title{
Peningkatan Produksi Saponin pada Kultur Kalus Ginseng Jawa (Talinum paniculatum Gaertn) dengan Penambahan Ekstrak Yeast
}

\section{Enhancement of Saponin Production in Callus Culture Javanese Ginseng (Talinum paniculatum Gaertn) with the Addition of Yeast Extract}

\author{
Amelia Dena ${ }^{1}$, Ratih Restiani ${ }^{1 *}$, dan Dwi Aditiyarini ${ }^{1}$ \\ ${ }^{1}$ Fakultas Bioteknologi, Universitas Kristen Duta Wacana, Yogyakarta, Indonesia
}

\begin{abstract}
Abstrak
Ginseng jawa (Talinum paniculatum Gaertn) merupakan tanaman yang dimanfaatkan dalam pengobatan tradisional masyarakat Indonesia. T. paniculatum berkhasiat dalam meningkatkan nafsu makan dan afrodisiaka. Upaya peningkatan produksi saponin pada T. paniculatum memerlukan metode yang efektif yaitu elisitasi. Ekstrak yeast (Saccharoyces cerevisiae) digunakan sebagai elisitor karena kemampuannya dalam memproduksi metabolit sekunder. Penelitian ini bertujuan untuk mengetahui pengaruh konsentrasi elisitor ekstrak yeast $(0,025 \%, 0,05 \%, 0,075 \%, 0,1 \%$, dan 0,5\%) dan waktu inkubasi (1, 2, dan 3 minggu) terhadap biomassa dan produksi saponin dari kultur kalus daun T. paniculatum. Media yang digunakan adalah MS (Murashige and Skoog). Identifikasi saponin menggunakan KLT (Kromatografi Lapis Tipis). Hasil menunjukkan konsentrasi ekstrak yeast dan waktu inkubasi tidak berpengaruh secara signifikan dalam meningkatkan biomassa kalus T. paniculatum. Konsentrasi ekstrak yeast 0,075\% dengan waktu inkubasi 3 minggu menghasilkan luas noda saponin tertinggi yaitu $0,549 \mathrm{~cm}^{2}$.
\end{abstract}

Kata kunci: Saponin, Talinum paniculatum Gaertn, Ekstrak yeast.

\begin{abstract}
Javanese ginseng (Talinum paniculatum Gaertn) is a plant used in traditional Indonesian medicine. T. paniculatum is efficacious in increasing appetite and aphrodisiac. Efforts to increase saponin production in T. paniculatum require an effective method, namely elicitation. Yeast extract is commonly used as an elicitor because of its ability to produce secondary metabolites. This study aims to determine the effect of yeast extract elicitor concentration $(0.025 \%, 0.05 \%, 0.075 \%, 0.1 \%$, and $0.5 \%)$ and incubation time $(1,2$, and 3 weeks) of biomass and saponin production from callus culture of T. paniculatum leaves. The medium used was MS (Murashige and Skoog). Saponin identification using TLC (Thin Layer Chromatography). The results showed the effect of yeast extract elicitor and incubation time does not have a significant effect in increasing the growth of $T$. paniculatum callus. Yeast extract concentration of $0.075 \%$ with an incubation time of 3 weeks resulted in the highest saponin stain area of $0.549 \mathrm{~cm}^{2}$.
\end{abstract}

Keywords: Saponin, Talinum paniculatum Gaertn, Yeast extract.

\footnotetext{
*Corresponding author:

Ratih Restiani

Fakultas Bioteknologi, Universitas Kristen Duta Wacana,

J1. Wahidin Sudirohusodo 5-25 Yogyakarta, 55224 Indonesia

Email : ratih.restiani@staff.ukdw.ac.id
} 


\section{Pendahuluan}

Kebutuhan obat-obatan dari tanaman semakin meningkat. Riset Obat dan Tanaman Jamu (RISTOJA) berhasil mengidentifikasi 1.159 tanaman (Balitbangkes, 2015). Salah satu tanaman yang dijadikan sebagai tanaman obat adalah ginseng jawa (Talinum paniculatum Gaertn). Rahmi et al. (2011), menyatakan bahwa salah satu uji kandungandanefektivitas saponin berpotensi dalam menjaga viabilitas sperma. Berdasarkan uji fitokimia, T. paniculatum mengandung senyawa metabolit sekunder diantaranya adalah saponin, flavonoid, tannin, triterpen, polifenol, dan minyak atsiri (Saroni et al., 1999). Saponin merupakan senyawa yang paling banyak dimanfaatkan dari tanaman T. paniculatum (Solichatun et al., 2005). Manitto (1992), menyatakan bahwa saponin memiliki nilai ekonomi yang tinggi dalam penggunaannya sebagai bahan dasar industri hormon seks, kortikosteroid, dan turunan steroid. Potensi T.paniculatum sebagai tanaman obat menyebabkan peningkatan budidaya tanaman ini untuk menghasilkan senyawa metabolit sekunder dalam skala besar. Akan tetapi, budidayanya menghadapi permasalahan terkait produktivitas yang dipengaruhi oleh faktor lingkungan dan penyakit. Hal ini tentu berdampak pada rendahnya produksi senyawa metabolit sekunder.

Permasalahan di atas dapat diatasi dengan metode kultur in vitro. Metode kultur in vitro dapat digunakan untuk menghasilkan metabolit sekunder. Akan tetapi konsentrasi metabolit sekunder yang dihasilkan relatif rendah. Metode elisitasi dapat menjadi metode alternatif untuk mengatasi masalah tersebut. Baenas et al (2014), menyatakan bahwa elisitor merupakan senyawa yang merangsang semua jenis pertahanan tanaman dan meningkatkan metabolit sekunder. Keberhasilan dalam elisitasi dipengaruhi oleh faktor lingkungan, konsentrasi elisitor, jenis elisitor, dan waktu kontak dengan elisitor. Elisitor terbagi menjadi dua antara lain elisitor biotik dan abiotik. Elisitor biotik terdiri atas beberapa jenis antara lain bakteri, jamur, virus, kitosan, dan kitin, sedangkan elisitor abiotik terdiri atas beberapa jenis senyawa kimia antara lain senyawa anorganik dan logam berat (Sharma et al., 2011; Patel \& Krishnamurthy, 2013). Salah satu elisitor biotik yang sering digunakan adalah ekstrak yeast. Ekstrak yeast memiliki kemampuan untuk merangsang mekanisme pertahanan, yang menyebabkan peningkatan produksi metabolit sekunder (Abraham et al., 2011). Ekstrak yeast memiliki kandungan asam amino, peptida, karbohidrat, garam (Milic et al., 2007), dan vitamin yang bermanfaat bagi pertumbuhan (Widiastoety et al., 2003). Ekstrak yeast memiliki kandungan nitrogen yang merupakan komponen protein dan asam nukleat yang berperan dalam proses fisiologis (Widiastoety et al., 2003). Kelebihan ekstrak yeast sebagai elisitor antara lain mudah diperoleh dan tidak bersifat patogen bagi manusia (Hariyum, 1986). Syahrial et al. (2018) berhasil meningkatkan luas noda saponin menggunakan elisitor $S$. cerevisiae pada kultur akar adventif $T$. paniculatum. Namun elisitasi pada kultur kalus T. paniculatum menggunakan ekstrak yeast belum banyak diteliti, sehingga dalam penelitian ini dilakuan variasi konsentrasi dan waktu inkubasi elisitor. Penelitian ini bertujuan untuk mengetahui pengaruh konsentrasi ekstrak yeast dan waktu inkubasi terhadap biomassa kalus dan produksi saponin melalui kultur kalus menggunakan eksplan daun ginseng jawa (T. paniculatum) melalui kultur in vitro.

\section{Materi dan Metode}

Penelitian dilaksanakan di Laboratorium Kultur Jaringan Fakultas Bioteknologi Universitas Kristen Duta Wacana (UKDW), Yogyakarta. Penelitian dilakukan secara eksperimental dengan menggunakan rancangan acak lengkap faktorial. Alat-alat yang digunakan untuk produksi kalus dan uji saponin adalah Laminar Air Flow (LAF), autoclave, timbangan analitik, waterbath, $\mathrm{pH}$ meter, gelas beker, erlenmeyer, cawan petri, tabung reaksi, plat TLC jenis silica gel GF 254, mikropipet, bunsen, pinset, skalpel, dan kompor. Bahan yang digunakan adalah eksplan daun nomor ketiga dari pucuk $T$. paniculatum yang berumur 3-4 bulan secara ex vitro yang diperoleh dari Merapi Farma Herbal. 


\section{Pembuatan Media MS (Murashige E Skoog)}

Pembuatan media MS (Murashige $\mathcal{E}$ Skoog) diawali dengan mencampurkan bahan-bahan makronutrien $\left(\mathrm{NH}_{4} \mathrm{NO}_{3}\right.$ 1,65 g/L, $\mathrm{KNO}_{3} 1 \mathrm{~g} / \mathrm{L}, \mathrm{MgSO} 4.7 \mathrm{H}_{2} \mathrm{O}$ 0,37 $\mathrm{g} / \mathrm{L}$, dan $\left.\mathrm{KH}_{2} \mathrm{PO} 40,17 \mathrm{~g} / \mathrm{L}\right), 1 \mathrm{ml} / \mathrm{L}$ stok mikronutrien, $5 \mathrm{ml} / \mathrm{L}$ stok iron, $4 \mathrm{ml} / \mathrm{L}$ stok vitamin, 0,1 gr/L Myo-inositol 0,1, dan Zat Pengatur Tumbuh (ZPT) dengan kombinasi 2,4-D dan kinetin perbandingan 2:3. Selanjutnya dilakukan pengukuran derajat keasaman. Derajat keasaman pada media diukur menggunakan $\mathrm{pH}$ meter. $\mathrm{pH}$ media berkisar pada 5,7-5,8. Pengaturan $\mathrm{pH}$ dilakukan dengan penambahan $\mathrm{NaOH}$ 0,1

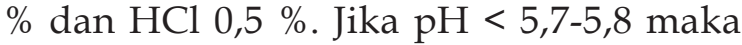
akan ditambahkan $\mathrm{NaOH}$ dan jika $>5,7-$ 5,8 maka akan ditambahkan $\mathrm{HCl}$ hingga angka pada $\mathrm{pH}$ meter menunjukkan 5,7-5,8. Langkah selanjutnya adalah menambahkan agar kedalam media sambil di aduk hingga mendidih. Media yang sudah masak dituang kedalam botol-botol kultur steril kemudian ditutup menggunakan aluminium foil dan perkamen. Media selanjutnya disterilisasi menggunakan autoclave dengan suhu $120^{\circ} \mathrm{C}$ selama 20 menit dengan tekanan 15 lbs. Setelah dilakukan sterilisasi, media dikeluarkan dan disimpan di ruang kultur.

Elisitor yang digunakan dalam penelitian ini adalah ekstrak yeast (Oxoid) yang diperoleh dari Laboratorium Dasar Fakultas Bioteknologi, UKDW. Pembuatan media elisitor dilakukan sesuai dengan komposisi dalam pembuatan media MS dengan ditambahkan ekstrak yeast sesuai dengan perlakuan $(0 \%, 0,025 \%, 0,05 \%$, $0,075 \%, 0,1 \%$, dan $0,5 \%)$. Tahap selanjutnya dilakukan pengukuran derajat keasaman yang sesuai yaitu 5,7-5,8. Media dimasak hingga mendidih dan dilanjutkan dengan menuangkan media ke dalam beberapa botol kultur. Media disterilisasi pada suhu $120^{\circ} \mathrm{C}$ selama 20 menit dengan tekanan 15 lbs.

\section{Sterilisasi Alat dan Bahan}

Pada tahap ini dilakukan sterilisasi alat, ruang kerja, dan eksplan. Alat yang terbuat dari kaca dan stainless disterilisasi menggunakan oven dengan suhu $150^{\circ} \mathrm{C}$ selama satu jam. Ruang kerja berupa laminar air flow disterilkan dengan cara disemprotkan alkohol 70\%. Kemudian alat dan ruang kerja disinari dengan sinar UV selama kurang lebih satu jam. Sterilisasi eksplan daun T. paniculatum dibagi menjadi 2 tahap yaitu prasterilisasi dan sterilisasi. Tahap pra-sterilisasi dilakukan dengan mencuci daun dengan air mengalir, kemudian daun direndam dalam larutan deterjen 10\% dan tiga tetes tween 80, digojok perlahan selama empat puluh lima detik. Daun dibilas dengan akuades sebanyak tiga kali, selanjutnya dibilas dengan akuades steril dan dimasukkan ke dalam cawan petri steril. Tahap sterilisasi dilakukan dengan cara daun T. paniculatum dimasukkan ke dalam alkohol 70\% selama 3 menit, kemudian dibilas dengan akuades steril sebanyak tiga kali.

\section{Inokulasi Kalus}

Inokulasi eksplan daun ke dalam medium MS untuk induksi kalus dilakukan dengan cara diambil daun yang telah disterilisasi. Daun dipotong mengenai tulang daun dengan berukuran 1,5 x 1,5 cm. Selanjutnya eksplan daun diinokulasikan ke botol kultur berisi media. Botol kultur ditutup dengan aluminium foil dan plastic wrap. Inokulasi eksplan dilakukan secara aseptis untuk mengurangi kontaminasi. Eksplan yang sudah diinokulasi dilakukan pengamatan dilakukan setiap dua hari sekali dengan parameter yang diamati yaitu persentase pertumbuhan kalus, warna dan tekstur kalus.

\section{Elisitasi}

Elisitasi dilakukan pada kultur kalus di fase stasioner yaitu kalus umur 58 hari (Wijaya et al., 2020). Elisitasi dilakukan pada kalus fase stasioner dengan dugaan pada fase ini kalus dapat menghasilkan metabolit sekunder secara maksimal ketika kontak dengan elisitor. Elisitasi dilakukan dengan memindahkan kalus tersebut ke media elisitor. Kalus diinkubasi selama 1, 2, dan 3 minggu. Kalus yang sudah dipanen dilakukan penimbangan berat kering sebagai data biomassa. 


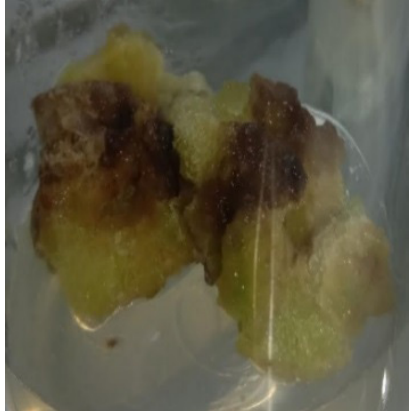

Gambar 1. Kalus ginseng jawa (T. paniculatum) fase 0

\section{Identifikasi Saponin dengan Kromatografi Lapis Tipis (KLT)}

Kalus yang sudah dielisitasi dikeringkan menggunakan oven $50^{\circ} \mathrm{C}$ selama 24 jam kemudian dihaluskan menggunakan mortal. Bubuk kalus sebanyak 0,1 g diekstraksi menggunakan 10 mL etanol 96\%, kemudian dipanaskan dalam waterbath selama 45 menit dengan suhu $80^{\circ} \mathrm{C}$. Ekstrak disaring menggunakan kertas saring dan dipekatkan hingga $0,2 \mathrm{~mL}$ menggunakan waterbath $80^{\circ} \mathrm{C}$ (Manuhara et al., 2015).

Identifikasi saponin pada kalus $T$. paniculatum menggunakan KLT(Kromatografi Lapis Tipis). Uji KLT dilakukan untuk mengidentifikasi dengan membandingkan nilai Rf, luas noda saponin, dan intensitas warna yang diamati dengan skoring. Larutan standar yang digunakan adalah standar saponin (Merck) 5\% +1 mL aquades. Ekstrak dan larutan standar saponin ditotolkan pada plat KLT yang telah di oven 1 jam dengan suhu $100^{\circ} \mathrm{C}$ kemudian dielusi menggunakan pelarut propanol : air dengan perbandingan $14: 3$. Selanjutnya untuk penentuan bercak pemisahan pada KLT dilakukan dengan menyemprotkan reagen anisaldehid $(0,5 \mathrm{~mL}$ anisaldehid, $10 \mathrm{~mL}$ asam asetat glasial, 85 $\mathrm{mL}$ etanol, dan $5 \mathrm{~mL}$ asam sulfat) kemudian dikeringkan menggunakan oven pada suhu $110^{\circ} \mathrm{C}$ selama 5-6 menit (Manuhara et al, 2015). Selanjutnya dihitung luas noda saponin dan nilai Rf. Nilai Rf dihitung menggunakan rumus sebagai berikut:

\section{Hasil \\ Produksi Kalus}

Pengaruh konsentrasi ekstrak yeast dan waktu inkubasi terhadap pertumbuhan kalus ginseng jawa (T. paniculatum) diukur berdasarkan berat kering kalus ginseng jawa yang telah dipanen dan diekstraksi. Grafik rerata ditunjukkan pada Gambar 2.

\section{Analisis Kromatografi Lapis Tipis (KLT)}

Dilakukan uji saponin terhadap ekstrak kalus ginseng jawa (T. paniculatum) dengan Kromatografi Lapis Tipis (KLT). Hasil uji KLT dapat dilihat pada Gambar 3 dan 4.

\section{Hubungan Biomassa dan Produksi Saponin \\ Grafik hubungan antara biomassa dan produksi saponin pada ginseng jawa (Talinum paniculatum Gaertn) disajikan dalam Gambar 5.}

\section{Pembahasan}

Elisitasi dilakukan pada kalus fase stasioner dengan dugaan pada fase ini kalus dapat menghasilkan metabolit sekunder secara maksimal ketika kontak dengan elisitor. Pemberian elisitor akan menstimulasi pembentukan metabolit sekunder dengan mengaktifkanjalur sekunder dalam merespon stres (Ningsih, 2014). Kalus yang terbentuk pada penelitian ini memiliki tekstur remah dan berwarna cokelat kehijauan (Gambar 1). Kalus yang terbentuk pada eksplan memiliki tekstur yang berbeda-beda. Turhan (2004)
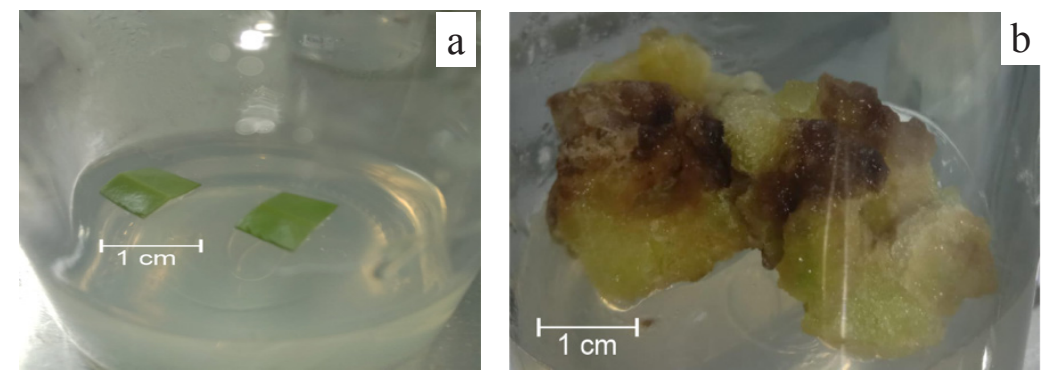

Gambar 2. Eksplan daun hari ke-0 (a) dan kalus ginseng jawa (T. paniculatum) hari ke-58 (b) 


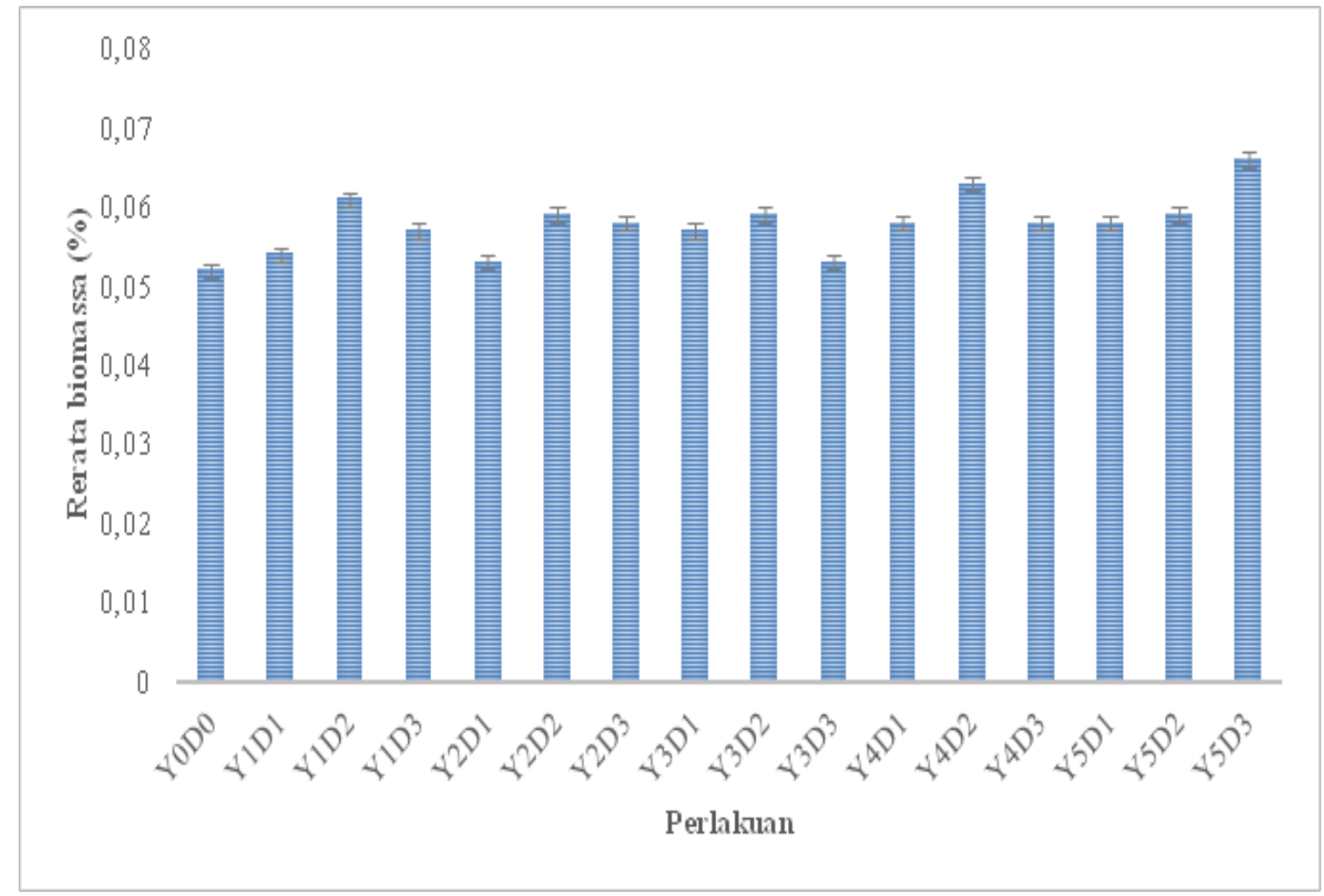

Gambar 2. Grafik rerata biomassa kalus ginseng jawa (Talinum paniculatum Gaertn)

Keterangan: (Std) standar saponin 5\%, (Y0) kontrol, (Y1) ekstrak yeast 0,025\%, (Y2) ekstrak yeast 0,05\%, (Y3) ekstrak yeast $0,075 \%$, (Y4) ekstrak yeast $0,1 \%$, (Y5) ekstrak 0,5\%, (D0) waktu inkubasi 0 hari, (D1) waktu inkubasi 1 minggu, (D2) waktu inkubasi 2 minggu, dan (D3) waktu inkubasi 3 minggu.

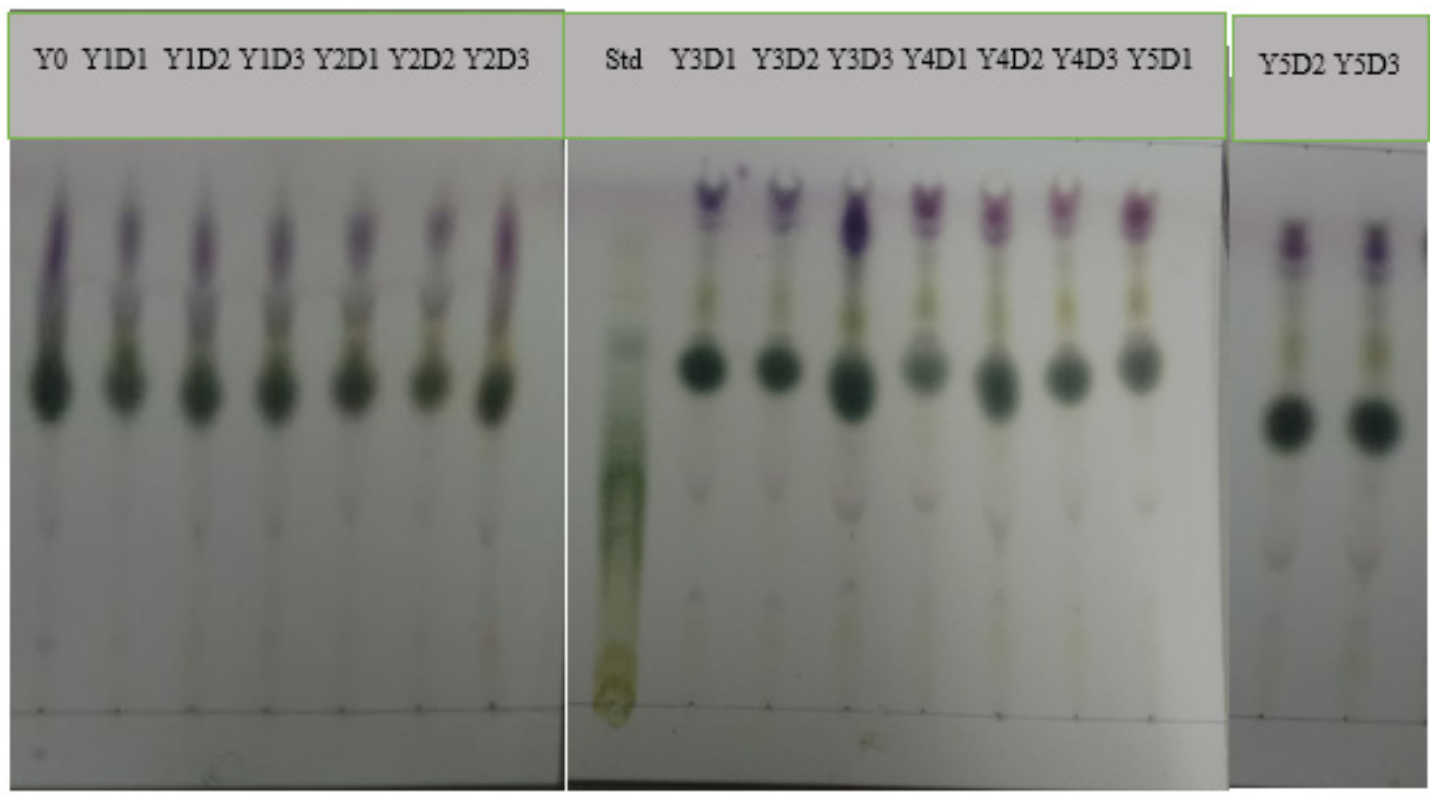

Gambar 3. Hasil uji saponin dengan Kromatografi Lapis Tipis (KLT) Keterangan: (Std) standar saponin $5 \%$, (Y0) kontrol, (Y1) ekstrak yeast 0,025\%, (Y2) ekstrak yeast 0,05\%, (Y3) ekstrak yeast 0,075\%, (Y4) ekstrak yeast 0,1\%, (Y5) ekstrak yeast 0,5\%, (D0) waktu inkubasi 0 hari, (D1) waktu inkubasi 1 minggu, (D2) waktu inkubasi 2 minggu, dan (D3) waktu inkubasi 3 minggu. 


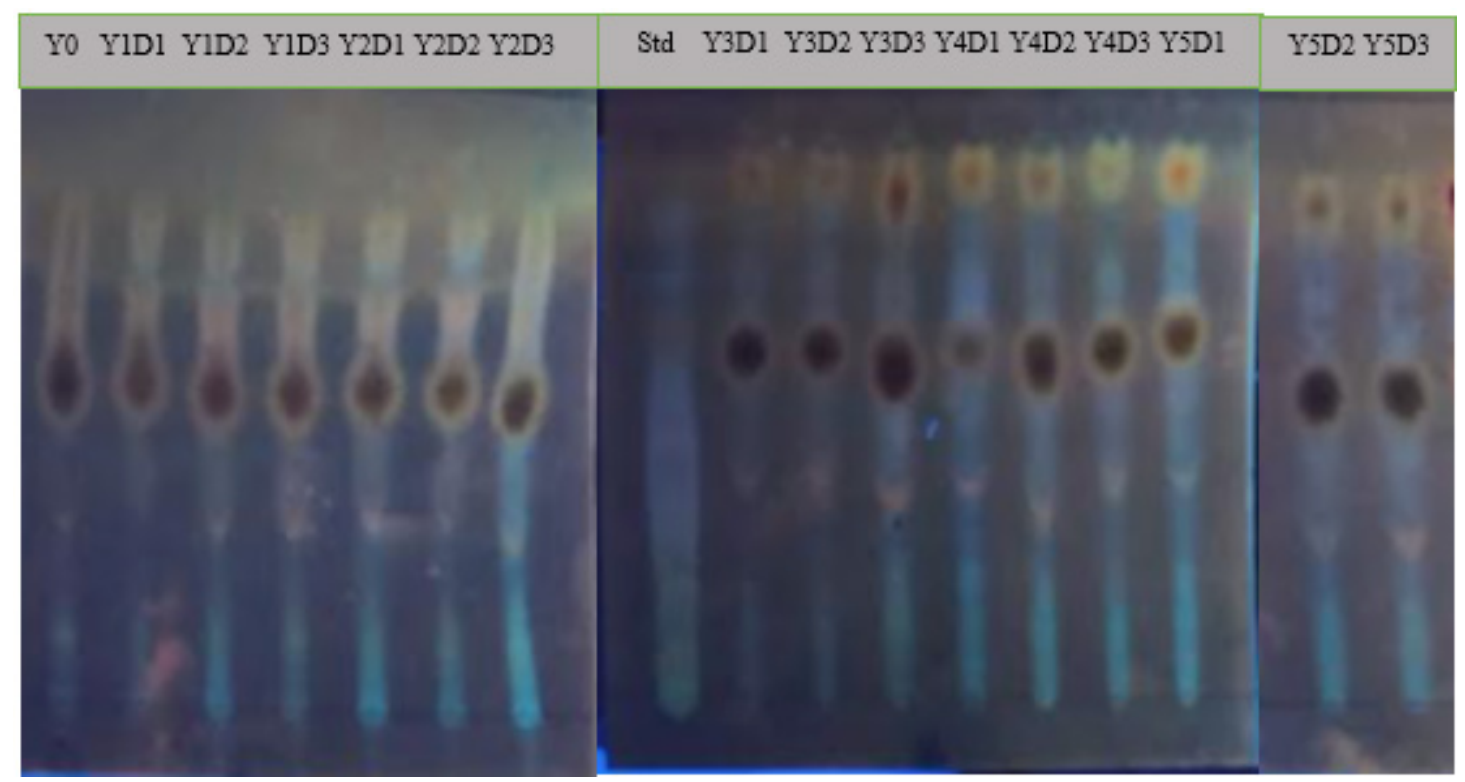

Gambar 4. Hasil uji saponin dengan Kromatografi Lapis Tipis (KLT) penampakan di bawah UV. Keterangan: (Std) standar saponin 5\%, (Y0) kontrol, (Y1) ekstrak yeast 0,025\%, (Y2) ekstrak yeast 0,05\%, (Y3) ekstrak yeast 0,075\%, (Y4) ekstrak yeast 0,1\%, (Y5) ekstrak yeast 0,5\%, (D0) waktu inkubasi 0 hari, (D1) waktu inkubasi 1 minggu, (D2) waktu inkubasi 2 minggu, dan (D3) waktu inkubasi 3 minggu.

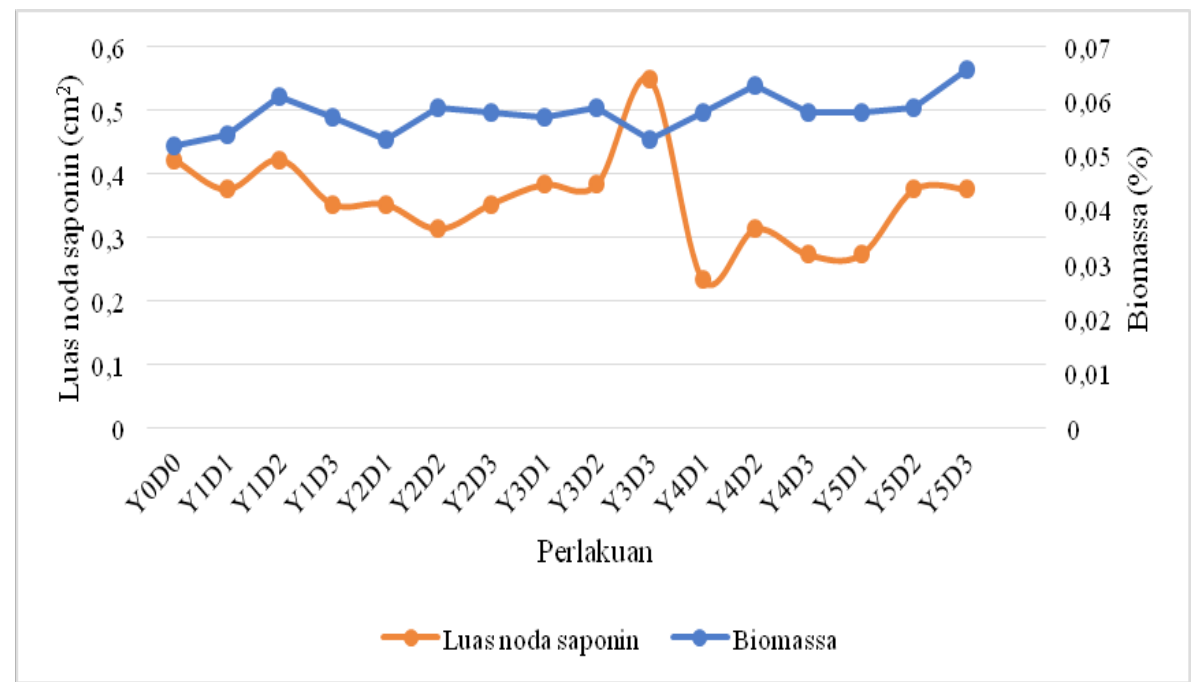

Gambar 5. Grafik hubungan antara biomassa dan produksi saponin pada ginseng jawa (Talinum paniculatum Gaertn)

menyatakan bahwa tekstur kalus terbagi menjadi tiga macam yaitu kompak (nonfriable), intermediet, dan remah (friable). Tekstur kalus yang berbeda tersebut sangat dipengaruhi oleh tipe jaringan eksplan dan kombinasi ZPT yang digunakan dalam menginduksi kalus (Makunga et al., 2005). Kalus T. paniculatum yang terbentuk dari minggu pertama hingga minggu ke-8 memiliki tekstur yang remah. Kalus yang bertekstur remah memiliki tekstur yang lunak dan mudah terpisah. Tektur kalus remah dianggap baik untuk memperbanyak jumlah kalus. Hal ini diketahui bahwa pemberian 2,4-D jenis auksin dapat menginduksi pembelahan dan pertumbuhan sel. Warna kecokelatan pada kalus menunjukkan bahwa kalus mulai mengalami penuaan serta berkurangnya nutrisi pada media. Warna hijau pada kalus menunjukkan kalus mampu membentuk klorofil. Ashokhan et al. (2020) menyatakan bahwa perbedaan warna 
Tabel 1. Data Pengamatan Sampel Kromatografi Lapis Tipis (KLT)

\begin{tabular}{cccc}
\hline Sampel KLT & Rf & $\begin{array}{c}\text { Luas Noda } \\
\text { Saponin }\left(\mathrm{cm}^{2}\right)\end{array}$ & Warna \\
\hline $\begin{array}{c}\text { Standar } \\
\text { Saponin (5\%) }\end{array}$ & 0,60 & 0,235 & 1 \\
Y0D0 & 0,50 & 0,423 & 4 \\
Y1D1 & 0,51 & 0,376 & 3 \\
Y1D2 & 0,50 & 0,423 & 4 \\
Y1D3 & 0,50 & 0,353 & 4 \\
Y2D1 & 0,52 & 0,353 & 3 \\
Y2D2 & 0,52 & 0,314 & 2 \\
Y2D3 & 0,51 & 0,353 & 4 \\
Y3D1 & 0,58 & 0,384 & 5 \\
Y3D2 & 0,57 & 0,384 & 4 \\
Y3D3 & 0,56 & 0,549 & 5 \\
Y4D1 & 0,58 & 0,235 & 2 \\
Y4D2 & 0,56 & 0,314 & 3 \\
Y4D3 & 0,57 & 0,274 & 3 \\
Y5D1 & 0,52 & 0,274 & 2 \\
Y5D2 & 0,52 & 0,376 & 5 \\
Y5D3 & 0,51 & 0,376 & 5 \\
\hline
\end{tabular}

Keterangan: Angka 1 hingga 5 menunjukkan warna paling pudar hingga pekat (menunjukkan sedikit-banyaknya saponin pada sampel).

kalus hjau, coklat dan krem menghasilkan kandungan metabolit sekunder Azadirachtin yang berbeda secara signifikan pada kultur kalus Zadirachta indica, dimana kalus yang berwarna hijau menunjukkan konsentrasi AZA lebih tinggi dibandingkan kalus berwarna coklat dan krem. Faktorfaktor yang mempengaruhi inisiasi kalus adalah media, ZPT, cahaya, dan kondisi lingkungan. Hendaryono dan Wijayani (1994), menyatakan bahwa beragam warna pada kalus disebabkan oleh pigmentasi, pengaruh cahaya dan sumber eksplan.

Gambar 2 menunjukkan rerata biomassa kalus T. paniculatum. Hasil menunjukkan kontrol memiliki rerata biomassa terendah dibandingkan dengan semua perlakuan yang diberi elisitor. Hal ini menunjukkan bahwa perlakuan pemberian elisitor ekstrak yeast dapat meningkatkan berat kering (biomassa) pada kalus T. paniculatum. Akan tetapi, hasil analisa statistik ANOVA menunjukkan tidak ada perbedaan nyata terhadap pengaruh perlakuan elisitasi terhadap biomassa kalus T. paniculatum. Hal ini disebabkan oleh konsentrasi ekstrak yeast yang terlalu tinggi sehingga menghambat proses pertumbuhan kalus.

Hasil menunjukkan biomassa tertinggi yaitu pada perlakuan Y5D3 (perlakuan elisitor ekstrak yeast 0,5\% dengan waktu inkubasi 3 minggu). Biomassa terendah adalah kontrol. Perlakuan elisitor ekstrak yeast $0,05 \%$ dengan waktu inkubasi 1 minggu menunjukkan rerata biomassa terendah kedua. Hasil tersebut menunjukkan rerata biomassa yang sama dengan perlakuan 0,075\% dengan waktu inkubasi 3 minggu.

Identifikasi kandungan saponin pada ekstrak kalus T. Paniculatum menggunakan Kromatografi Lapis Tipis (KLT). Hasil ditunjukkan pada Gambar 3 dan 4 yang menunjukkan bercak hijau setelah disemprot dengan anisaldehide- $\mathrm{H}_{2} \mathrm{SO}_{4}$. Hal ini mengindikasikan kandungan saponin pada ekstrak kalus T. paniculatum.

Hasil identifikasi menunjukkan luas noda saponin tertinggi yaitu $0,549 \mathrm{~cm}^{2}$ pada pemberian ekstrak yeast dengan konsentrasi 0,075\% dengan waktu inkubasi 3 minggu (Tabel 1). Hasil tersebut didukung dengan warna sampel yang pekat berdasarkan skoring warna yaitu 5 dari 5 . Penelitian yang dilakukan Syahrial et al. (2018), menunjukkan luas noda saponin tertinggi sebesar $0,28 \mathrm{~cm}^{2}$ pada konsentrasi ekstrak $S$. cerevisiae $0,025 \%$ dengan waktu inkubasi 2 minggu pada akar adventif T. paniculatum. Pada penelitian ini, luas noda saponin tertinggi ditunjukkan pada konsentrasi $0,075 \%$ dengan waktu inkubasi 3 minggu. Hasil ini menunjukkan bahwa ekstrak yeast yang digunakan dalam kultur kalus T. paniculatum membutuhkan konsentrasi ekstrak yeast yang lebih tinggi untuk menghasilkan saponin yang lebih banyak. Faktor lain yang dapat berpengaruh terhadap produksi metabolit sekunder dalam kultur in vitro antara lain jenis media yang digunakan, kondisi lingkungan, tipe kultur, dan jenis eksplan. Tipe kultur pada penelitian Syahrial et al. (2018), menggunakan kultur akar adventif sehingga akar yang terbentuk secara keseluruhan berkontakan langsung dengan media elisitor.

Gambar 5 menunjukkan hubungan antara biomassa dan produksi saponin pada kalus T. paniculatum. Perlakuan Y3D3 
yaitu pemberian elisitor ekstrak yeast 0,075\% dengan waktu inkubasi 3 minggu menunjukkan peningkatan saponin diikuti dengan penurunan biomassa. Perlakuan elisitor ekstrak yeast 0,075\% dengan waktu inkubasi 3 minggu menghasilkan saponin tertinggi. Penurunan biomassa dapat terjadi karena nutrisi di dalam media sudah mulai berkurang. Penelitian yang dilakukan oleh Silalahi (2010), menunjukkan pemberian elisitor ekstrak yeast dari $S$. cerevisiae menurunkan biomassa pada kalus Catharantus roseus. Hal ini diikuti dengan peningkatan senyawa fenolik dan metabolit sekunder. Pada perlakuan Y5D3 yaitu perlakuan dengan elisitor ekstrak yeast $0,5 \%$ dengan waktu inkubasi 3 minggu menunjukkan peningkatan biomassa tertinggi diikuti dengan penurunan produksi saponin. Diduga pada pemberian elisitor ekstrak yeast dengan konsentrasi yang lebih tinggi dapat menghambat biosintesis saponin pada T. paniculatum. Elisitor memiliki molekul seperti oligosakarida, peptida, lipid, dan protein dimana molekul tersebut merupakan molekul yang dilepaskan atau diproduksi oleh patogen (Boller, 1995), yang dapat memberikan informasi bagi tumbuhan untuk melihat dan mengenali sinyal dari patogen oleh reseptor yang terlokalisasi di permukaan sel (D'Ovidio et al., 2004). Ekstrak yeast merangsang mekanisme pertahanan sehingga meningkatkan produksi metabolit sekunder (Abraham et al., 2011).

Pemberian berbagai konsentrasi ekstrak yeast dan waktu elisitasi berpengaruh terhadap pertumbuhan kalus dan produksi saponin pada kultur kalus daun T. paniculatum. Ekstrak yeast memiliki kandungan asam amino, peptida, karbohidrat, garam (Milic et al., 2007), dan vitamin yang bermanfaat bagi pertumbuhan (Widiastoety et al., 2003). Berdasarkan Kimball dan Jefferson (2006), asam amino mampu memodulasi protein yang terlibat dalam proses translasi mRNA dalam ekspresi gen. Berdasarkan hal tersebut, kandungan asam amino dalam ekstrak yeast diduga dapat meningkatkan ekspresi gen isopentenyl pyrophosphate isomerase (IPPI) dan farnesyl diphosphate synthase (FPS). Kedua enzim tersebut merupakan enzim yang terlibat dalam biosintesis senyawa terpenoid atau isoprenoid melalui jalur mevalonat (Herbert, 1981). Saponin merupakan salah satu kelompok senyawa terpenoid. Biosintesis senyawa terpenoid diawali dengan pembentukan prekursor isopentenyl pirophoshate (IPP). Kemudian IPP akan diisomerisasi menjadi dimethylallyl diphosphate (DMAPP) dengan bantuan enzim IPPI, yang merupakan kelompok enzim isomerisasi. Selain IPPI, FPS juga merupakan enzim kunci dalam jalur biosintesis senyawa terpenoid. FPS berperan dalam pembentukan farnesyl diphosphate (FPP) dari prekursor DMAPP. FPP merupakan prekursor utama dalam pembentukan sesquiterpenoid. Menurut Rahimi et al. (2014), enzim FPS dan IPPI terekspresi lebih tinggi ketika dilakukan penambahan ekstrak yeast yang mengakibatkan produksi saponin meningkat. Para peneliti juga menduga bahwa dengan adanya beberapa kation yaitu $\mathrm{Zn}, \mathrm{Ca}$, dan $\mathrm{Co}$ dalam ekstrak yeast berperan sebagai stressor elisitor abiotik (Srivastava et al., 2014).

\section{Kesimpulan}

Pemberian elisitor ekstrak yeast tidak berpengaruh secara signifikan terhadap peningkatan pertumbuhan kalus $T$. paniculatum. Pemberian elisitor ekstrak yeast konsentrasi $0,075 \%$ dengan waktu inkubasi 3 minggu merupakan perlakuan yang menghasilkan saponin terbanyak. Luas noda saponin yang dihasilkan adalah 0,549 $\mathrm{cm}^{2}$ dan memiliki warna sampel yang pekat melalui skoring yaitu 5 dari 5. Disarankan pada penelitian selanjutnya menggunakan densitometer dan HPLC (High Performance Liquid Chromatography) untuk memperoleh data saponin yang lebih akurat.

\section{Daftar Pustaka}

Abraham, F., Bhatt, A., Lai Keng, C., Indrayanto, G., \& Shaida, F. (2011). Effect of yeast extract and chitosan on shoot proliferation, morphology and antioxidant activity of $C u r c u m a$ mangga in Vitro plantlets. African Journal of Biotechnology, 10(40), 7787-7795.

Ashokhan, S., Othman, R., Rahim, M. H., Karsani, S. A., \& Yaacob, J. S. (2020). 
Dena et al.

Effect of Plant Growth Regulators on Coloured Callus Formation and Accumulation of Azadirachtin, an Essential Biopesticide in Azadirachta indica. Plants, 9 (352), 1-17

Balitbangkes, Balai Besar Penelitian dan Pengembangan Tanaman Obat dan Obat Tradisional. (2015). Laporan Nasional Eksplorasi Pengetahuan Lokal Etnomedisin dan Tumbuhan Obat Berbasis Komunitas di Indonesia (Riset Tumbuhan Obat dan Jamu. Jakarta.

Baenas, N., Garcia-Viguera., C., \& Moreno., D.A. (2014). Elicitation: A tool for enriching the bioactive composition of foods. Molecules, 19, 13541-13563.

Boller, T. (1995). Chemoperception of Microbial Signals in Plant Cells. Annual Review Plant Biology, 46, 189-214.

D'Ovidio. R., Mattei. B., Roberti. S., \& Bellincampi, D. (2004). Polygalacturonases, polygalacturonaseinhibiting proteins and pectic oligomers in plant-pathogen interactions. Biochimica et Biophysica Acta, 1696, 237-244.

Hariyum, A. (1986). Pembuatan Protein Sel Tunggal. Waca Utama Pramesti: Jakarta.

Hendaryono, D. P. S \& Wijayani, A. (1994). Teknik Kultur Jaringan. Yogyakarta: Penerbit kanisius.

Herbert, R. B. (1981). The biosynthesis of secondary metabolites.

Kimball, S. R \& Jefferson, L. S. (2006). New functions for amino acids: effects on gene transcription and translation. The American of Journal Clinical Nutrition, 83(2), 500S-507S.

Makunga, N. P., Jager, A. K., van Staden, J. (2005). An improved system for the in vitro regeneration of Tapsia garganica via direct organogenesis - influence of auxins and cytokinins. Plant Cell, Tissue and Organ Culture, (82), 271-280.

Manitto, P. (1992). Biosintesis Produk Alami. Penerjemah: Koensoemardiyah. Semarang: IKIP Press.

Manuhara, Y. S. W., Kristanti, A. N., Utami, E.S.W. \& Yachya, A. (2015). Effect of Sucrose and Potassium Nitrate
Sciscitatio, Vol. 2, No. 1, Januari 2021

on Biomass and Saponin Content of Talinum paniculatum Gaertn. Hairy root in ballon-type bubble bioreactor. Asian Pasific Journal of Tropical Biomedicine, 5(12), 1027-1032.

Milic, T. V., Rakin, M., \& Slavica, S. M. (2007). Utilization of Baker's Yeast (Saccharomyces cerevisiae) for the Production of Yeast Extract: Effect of Different Enzymatic Treatment on Solid, Protein and Carbohydrate Recovery. Journal of the Serbian Chemical Society, 72(5), 451-457.

Ningsih \& Yulia. (2014). Pengaruh elisitor biotik dan abiotik pada produksi flavonoid melalui kultur jaringan tanaman. Bagian Biologi Farmasi, Fakultas Farmasi Universitas Jember, Indonesia

Patel, H \& Krishnamurthy, R. (2013). Elicitors in plant tissue culture. Journal of Pharmacognosy and Phytochemistry, 2(2), 60-65.

Rahmi, Eriani, K., \& Widya. (2011). Potency of Java Gingseng (Talinum paniculatum Gaertn.) Root Extract on Quality and Viability of Mice Sperm. Journal National. 11(1), 7-10.

Rahimi, S., Devi, B. S. R., Khorolragchaa, A., Kim, Y. J., Kim, J. H., Jung, S. K. \& Yang, D. C. (2014). Effect of salicylic acid and yeast extract on the accumulation of jasmonic acid and sesquiterpenoids in Panax ginseng adventitious roots. Russian Journal Plant Physiology, 61, 811-817.

Saroni, N., Y. Astuti., \& Adjirni. (1999). Pengaruh infus akar som jawa ( $T$. paniculatum) terhadap jumlah dan motilitas spermatozoa pada mencit. Warta Tumbuhan Obat Indonesia, 5(4), 13-14.

Sharma, M., Sharma, A., Kumar, A. \& Basu, S. K. (2011). Enhancement of secondary metabolites in cultured plant cells through stress stimulus. American Journal of Plant Physiology, 6(2), 50-71.

Srivastava, S. \& Srivastava, A. K. (2014). Effect of elicitors and precursors on azadirachtin production in hairy root culture of Azadirachta indica. Applied 
Biochemistry Biotechnology, 172, 22862297.

Silalahi, M. (2010). Elisitasi Peningkatan Produksi Ajmalisin Oleh Kalus Catharantus roseus (L.) G. Don. Berita Biologi, 10 (3).

Syahrial, B.R., Manuhara, S.W., Setiti, E. \& W.U. (2018). Pengaruh Elisitor Ekstrak Saccharomyces cerevisiae terhadap Biomassa dan Kadar Saponin Akar Adventif Talinum paniculatum (Jacq) Gaertn., Secara In-vitro. Departement of Biology, Faculty of Sains and Technology Airlangga University.

Solichatun, Anggarwulan, E. \& Mudyantini, W. (2005). Pengaruh Ketersediaan Air terhadap Pertumbuhan dan Kandungan Bahan Aktif Saponin Tanaman Gingseng Jawa (Talinum paniculatum Gaertn.). Biofarmasi, 3(2), 47-51.

Turhan, H. (2004). Callus Induction and Growth in Transgenic Potato Genotype. African Journal of Biotechnology, 3 (8), 375-378.

Widiastoety, D \& Kartikaningrum. (2003). Pemanfaatan Ekstrak Ragi dalam Kultur In Vitro Plantet Media Anggrek. Cianjur. J. Hort, 2, 60-66.

Wijaya, R., Restiani. R. \& Aditiyarini, D. (2020). Pengaruh Kitosan terhadap Produksi Saponin Kultur Kalus Daun Ginseng Jawa (Talinum paniculatum (Jacq.) Gaertn.). Prosiding Seminar Nasional Biologi, 5 (1), pp. 252-261. 